\title{
Erratum to: Estimation of glacial retreat and mass loss in Baspa basin, Western Himalaya
}

\author{
Vinay Kumar Gaddam ${ }^{1,3} \cdot$ Anil V. Kulkarni ${ }^{2}$ Anil Kumar Gupta ${ }^{3}$
}

Published online: 17 June 2016

(C) Korean Spatial Information Society 2016

\section{Erratum to: Spat. Inf. Res. \\ DOI:10.1007/s41324-016-0026-x}

Regrettably, there is an error in Acknowledgment section of the published article (10.1007/s41324-016-0026-x). The correct "Acknowledgments" should be as follows:

Acknowledgments The authors would like to thank the United States Geological Survey for Landsat imagery, National Remote Sensing
Center, Indian Space Research Organization, for Elevation datasets, Bhakra Beas Management Board, Chandigarh, for meteorological data, Divecha Center for Climate Change, Indian Institute of Science, and National Center for Antarctica and Ocean Research, India, for the financial support. Special thanks to Dr. Thamban Meloth, National Center for Antarctica and Ocean Research, Dr. H. S. Negi, Snow \& Avalanche Studies Establishment-DRDO, Dr. S.S. Randhawa, State Center on Climate Change, Himachal Pradesh, and Prof. Rajesh Kumar, Sharda University, for suggestions and support during field study. This is NCAOR contribution number 11/2016.
The online version of the original article can be found under doi:10.1007/s41324-016-0026-x.

\section{Vinay Kumar Gaddam}

gaddam_vinay@ymail.com

1 Cryosphere Science Division, ESSO-National Centre for Antarctic and Ocean Research, Vascodagama, India

2 Divecha Center for Climate Change, Indian Institute of Science, Bangalore, India

3 Department of Civil Engineering, Visvesvaraya Technological University, Belgaum, India 